MANAGEMENT OF THE SOW AND LITTER IN LATE PREGNANCY AND LACTATION IN RELATION TO PIGLET SURVIVAL AND GROWTH

\author{
P.R. ENGLISH and V. WILKINSON \\ School of Agriculture, University of Aberdeen, UK
}

The objectives of management in late pregnancy and lactation are to minimize the incidence of stillbirths, to maximize the number of livebirths at parturition and to improve the viability of these pigs. Thereafter, management must strive to minimize mortality and to produce healthy and well grown pigs at weaning. Treatment imposed in late pregnancy and lactation should be orientated towards achieving prompt conception following weaning and to providing the potential for establishing a large litter of viable piglets in the subsequent gestation.

Aspects relating to piglet mortality and its prevention will form the first part of this chapter followed by a consideration of supplementary feeding of the litter.

\title{
Piglet mortality
}

\section{EXTENT OF MORTALITY}

Losses from stillbirths range from $4-8 \%$ of all pigs born in most studies (Table 23.1), although considerably higher levels of stillbirths have been reported in isolated cases (Moore, Redmond and Livingston, 1965).

Table 23.1 ESTIMATES OF STILLBIRTH LOSSES

\begin{tabular}{llrl}
\hline Source & Country & Total born & $\begin{array}{l}\text { Stillbirths } \\
(\%)\end{array}$ \\
\hline Braude et al. (1954) & & 12.10 & 5.72 \\
Hutchinson et al. (1954) & Britain & 9.62 & 5.15 \\
Gracey (1955) & U.S.A. & 11.08 & 4.9 \\
Anon (1959) & Ireland & 11.00 & 6.04 \\
Bauman et al. (1966) & Britain & 10.07 & 5.67 \\
Sharpe (1966) & U.S.A. & 10.70 & 5.26 \\
English (1969) & & 11.21 & 4.21 \\
Randall and Penny (1970) & Britain & 11.69 & 7.9 \\
Randall (1972b) & Britain & 10.99 & 6.33 \\
Leman et al. (1972) & Britain & 10.65 & 6.83 \\
Nielsen et al. (1974) & Britain & 9.82 & 7.09 \\
Glastonbury (1976) & Illinois, USA & 10.16 & 5.9 \\
Meat and Livestock Commission (1980) & Britain & 10.4 & 5.8 \\
\hline
\end{tabular}


Table 23.2 PRE.WEANING MORTALITY

\begin{tabular}{lllll}
\hline Source & Country & $\begin{array}{l}\text { Weaning age } \\
\text { (weeks) }\end{array}$ & Born alive & $\begin{array}{l}\text { Mortality } \\
\text { (\% of livebirths) }\end{array}$ \\
\hline Braude et al. (1954) & Britain & 8 & 11.4 & 29.5 \\
Fraser (1966) & Jamaica & 6 & 9.6 & 20.8 \\
Sharpe (1966) & Britain & 6 & 10.75 & 21.4 \\
Ilančic et al. (1968) & Yugoslavia & 8 & 10.30 & 14.5 \\
English (1969) & Britain & 8 & 10.77 & 24.4 \\
Leman et al. (1972) & Illinois, USA & & 9.12 & 19.5 \\
Nielsen et al. (1974) & Denmark & & 9.56 & 17.8 \\
Glastonbury (1976) & New South Wales, & & 9.8 & 14.3 \\
& Australia & <19 days & 10.2 & 11.1 \\
Mcat and Livestock & Britain & $19-25$ days & 10.3 & 12.3 \\
Commission (1980) & & 26-32 days & 10.4 & 12.0 \\
& & 33-39 days & 10.5 & 13.5 \\
& & >39 days & 10.5 & 14.3 \\
& & Overall & 10.4 & 12.8 \\
\hline
\end{tabular}

The extent of pre-weaning losses has also been very variable ranging from 12 to almost $30 \%$ (Table 23.2). However, even the lowest levels of mortality reported constitute considerable losses. For example, a $12 \%$ mortality is equivalent to the loss of over 250 piglets/year in a 100 -sow herd.

It is very important to relate percentage losses to numbers born. In commercial terms, $10 \%$ pre-weaning mortality with 10 born alive (leaving 9 reared per sow) is considerably more serious than $20 \%$ mortality with 15 pigs born (leaving 12 reared per sow).

\section{CAUSES OF STILLBIRTH}

Stillbirths have been classified into Type I or pre-partum deaths (dead before start of parturition) and Type II or intrapartum deaths (dying during the parturition process) (Randall and Penny, 1967). Among other factors from which pre-partum deaths can result, infection during pregnancy such as that associated with the Smedi syndrome can be responsible (Dunne and Leman, 1975). In isolated cases, iron deficiency in the sow has been associated with a higher incidence of stillbirths (Moore, Redmond and Livingston, 1965) and, in such cases, administration of supplementary iron has helped to reduce the problem.

Of the total stillbirths, between 70 and $90 \%$ are of Type II or intrapartum deaths (Randall, 1972b; English and Smith, 1975) and foetal anoxia during parturition is recognized as being the major cause (Randall and Penny, 1967). Such anoxia is induced by decreased placental blood flow associated with uterine contractions or with occlusion or premature rupture of the umbilical cord or premature detachment of the placenta (Curtis, 1974).

Later born piglets are likely to suffer to a greater degree from anoxia because of the cumulative effects of successive contractions in reducing the oxygenation of the unborn piglets and also because of the greater risk of premature rupture of the umbilical cord or of detachment of the placenta 
as parturition progresses (English, 1969; Randall, 1972a,b). Thus, the incidence of intrapartum deaths tends to be concentrated in the second half of the birth order with about $70 \%$ being among the last three piglets born (Randall, 1972a,b; English, Smith and MacLean, 1977).

The incidence of intrapartum deaths increases markedly in older sows, probably because of poorer uterine muscle tone, and is also higher in larger litters (Anon, 1959; Sharpe, 1966; English, 1969; Randall and Penny, 1970; Bille et al., 1974; English et al., 1977). A higher percentage of stillbirths is also experienced in very small litters (Carmichael and Rice, 1920; Anon, 1959; Sharpe, 1966).

The same factors that increase the incidence of intrapartum deaths in later born pigs also render the later born survivors more anoxic at birth and probably less viable (English et al., 1977). The blood lactate level in newborn piglets provides a useful measure of the degree of anoxia suffered during parturition (Dawes et al. , 1963) and the relationship of lactate level to birth order is illustrated in Figure 23.1.

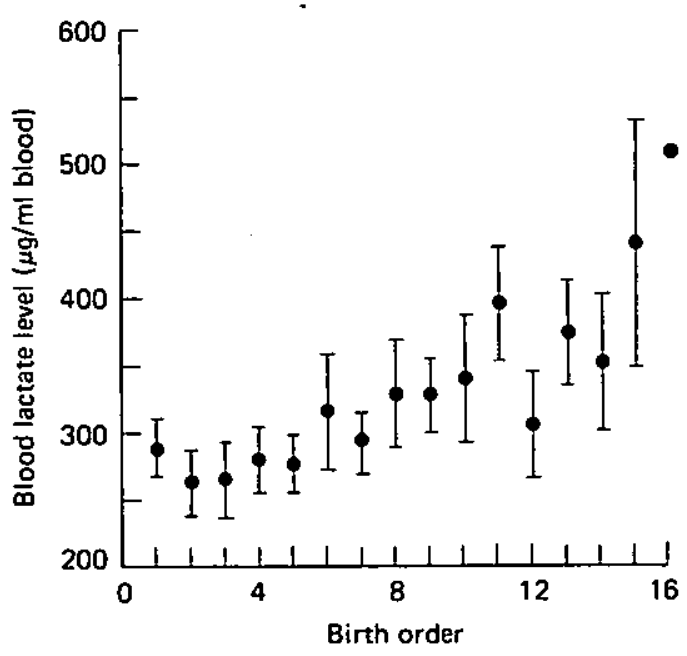

Figure 23.1 Blood lactate level in liveborn pigs at birth according to birth order (mean blood lactate \pm standard error)

The relationship between the level of anoxia in the liveborn piglet at birth and subsequent survival has not been clearly established. However, it is known that severe anoxia in utero may lead to depression of the central nervous system and irreversible brain damage (Stanton and Carroll, 1974). Miller and Miller (1965) considered that the unborn piglet during parturition was likely to suffer from irreversible brain damage within approximately five minutes following restriction of umbilical blood flow. Table 23.3 contains details of a comparison of blood lactate levels at birth of liveborn piglets which died before three weeks of age and those which survived after this time. Liveborn piglets dying before three weeks of age had a $26.5 \%$ higher blood lactate level at birth than those surviving after this stage, the difference between the two groups being significant $(P<0.01)$. Thus, it appeared that the liveborn pigs which died suffered 
Table 23.3 BLOOD LACTATE LEVELS AT BIRTH IN LIVEBORN PIGS (a) DYING BEFORE AND (b) SURVIVING TO 3 WEEKS OF AGE

\begin{tabular}{lcllll}
\hline & $\begin{array}{l}\text { Dying } \\
\text { before } \\
3 \text { weeks }\end{array}$ & $\begin{array}{l}\text { Surviving } \\
\text { 10 3 weeks }\end{array}$ & Difference & $\begin{array}{l}\text { S.E. of } \\
\text { difference } \\
\text { between } \\
\text { means }\end{array}$ & $\begin{array}{l}\text { Level of } \\
\text { significance } \\
\text { of difference }\end{array}$ \\
\hline $\begin{array}{l}\text { Number of piglets } \\
\begin{array}{l}\text { Mean blood lactate } \\
(\mu \mathrm{g} \text { lactate/ml blood) }\end{array}\end{array}$ & 583.3 & 252 & & & \\
\hline
\end{tabular}

"*Significant at $P<0.01$.

From English and Smith (1975)

from a higher degree of prenatal anoxia than those which survived. It seems probable that this may have contributed to their death.

\section{ATTEMPTS TO IMPROVE THE EFFICIENCY OF PARTURITION}

It has been established that inefficiencies associated with parturition result in increased incidence of intrapartum deaths and may reduce the viability of liveborn piglets. Various attempts have been made to increase the efficiency of the parturition process. One simple approach in commercial practice is to cull sows timeously since older sows take longer to farrow and have a higher incidence of intrapartum deaths (Friend, Cunningham and Nicholson, 1962; English, 1969; English et al., 1977). Other approaches to improving efficiency of parturition have included the administration of posterior pituitary extract which contains oxytocin, of oxytocin itself and of parasympathomimetic drugs. The main findings of such work are summarized in Table 23.4 .

While pituitary extract and oxytocin are used widely to stimulate uterine muscle contractions in cases of dystocia, their routine use in an attempt to increase the efficiency of parturition and reduce the incidence of intrapartum deaths has produced inconsistent and generally disappointing results (Asdell and Willman, 1941; Lee, 1977). The explanation is likely to be connected with the very short period over which oxytocin appears to be effective in stimulating uterine muscle contractions; its biological half life appears to be no more than five minutes (Denamur, 1965; Hayes and Van Demark, 1952). There is also the risk that if oxytocin is administered in excess it could produce uterine hypotonus (tetany) as it does in the human (Lloyd D.J., personal communication). In cases of dystocia in the human, administration of oxytocin is carried out by continuous intravenous infusion, this being regulated according to the rate and intensity of the contractions (Turnbull and Anderson, 1968). Brenner, Schulze and Gurtler (1978) appear to be the only workers who have used this approach in the pig but their findings provide no indications of the effect on the incidence of intrapartum deaths.

In work conducted to date, the parasympathomimetic drugs have given most promise in relation to possibilities for improving the efficiency of the parturition process. These synthetic compounds act on the parasympathetic nervous system, resulting in stimulation of smooth muscle contraction and acceleration of the parturition process. Parasympathomimetic drugs 
which have been evaluated include neostigmine, bethanecol, pilocarpine and carbachol. Sprecher et al. (1974) reported the effects of a 2 or $3 \mathrm{mg}$ injection of carbachol given after the birth of the first pig in two trials. While the treatment reduced birth interval by over $30 \%$ in both trials relative to untreated sows, only in the second trial was some reduction in the incidence of stillbirths evident. However, in later trials by Sprecher, Leman and Carlisle (1975) using carbachol, and by Lee (1977) using both bethanecol and pilocarpine, these drugs were administered midway through parturition in an attempt to accelerate the delivery of the last pigs in the litter, that is, those which are most at risk from intrapartum death through anoxia. In these trials stillbirth rate was reduced by over 0.5 pig/litter relative to controls. While these drugs were found to be equally effective in reducing the incidence of stilibirths, neostigmine was preferred because of the comparative absence of any unpleasant side effects. McInnes (1977) evaluated neostigmine in a large scale on-farm trial and claimed similar reductions in stillbirth rate to Sprecher, Leman and Carlisle (1975) and Lee (1977). However, neostigmine has not produced the same response in all trials since Hendrix et al. (1978) found no reduction in either birth interval, or in stillbirths relative to controls, in a trial in which piglets were removed from the sow as they were born. Such removal of piglets as they were born is likely to have reduced the stimulus for oxytocin release from the pituitary gland and may thus have affected the response to neostigmine (Murdoch, 1980).

In trials in which neostigmine has reduced the incidence of intrapartum deaths, it might be expected to decrease the degree of anoxia suffered by liveborn piglets and thus to increase their viability. However, this aspect has not yet been investigated in any of the studies reported.

\section{BASIC REQUIREMENTS OF THE NEWBORN PIGLET}

The newborn piglet has several basic requirements if it is to survive and thrive. The herd must have a good health status, the piglet must be anatomically normal, it must be provided with an adequate thermal environment so as to conserve scarce energy reserves, it requires adequate and regular nutrition and it must be protected from being overlain by its dam.

The causes of piglet mortality determined in various studies reflect the extent to which these basic requirements of the newborn piglet are, or are not, provided in practice.

\section{TIMING OF MORTALITY}

Over $50 \%$ of the losses of liveborn piglets occur within the first 2-3 days of life (Anon, 1959; Pomeroy, 1960; Bauman, Kadlec and Powlen, 1966; Sharpe, 1966; English, 1969; Fahmy and Bernard, 1971; English and Smith, 1975; Glastonbury, 1976). Such data, of course, underestimate the importance of this very early period in relation to losses, for many of the later deaths are triggered off by events in the first few hours of life 
Table 23.4 RESULTS OF EXPERIMENTS INVESTIGATING THE USE OF INFLUENCE PARTURITTON

\begin{tabular}{|c|c|c|c|c|}
\hline Workers & Compound & $\begin{array}{l}\text { No. animals in } \\
\text { study } \\
\text { Controls treated }\end{array}$ & Dose & $\begin{array}{l}\text { Method of } \\
\text { administration }\end{array}$ \\
\hline
\end{tabular}

\begin{tabular}{clc}
\hline Asdell and Willman & Pituitary \\
(1941) & extract
\end{tabular}

$\underset{\text { Muhrer et al. }}{\text { (1955) }}$ Oxytocin

(1)

43

$\begin{array}{ll}1 \text { or } 2 \mathrm{ml} & \text { s.c. }{ }^{(\mathrm{a})} \\ 1 \text { or } 2 \mathrm{ml} & \text { s.c. } \\ \text { Not less } & \text { i.m. } \\ \text { than } 20 \mathrm{iu} & \end{array}$

\begin{tabular}{|c|c|c|}
\hline Lee (1977) & Oxytocin & \\
\hline \multirow[t]{2}{*}{$\begin{array}{l}\text { Brenner et al. } \\
\text { (1978) }\end{array}$} & Oxytocin & $\begin{array}{l}\text { (1) } \\
\text { (2) }\end{array}$ \\
\hline & & (3) \\
\hline
\end{tabular}

$33 \quad 40$ iu i.m.

Sprecher et al.

(1975)

Lee (1977)

Mclnnes (1977)

Hendrix et al. $(1978)^{(\mathrm{c})}$

- Sprecher et al. (1974)

Sprecher et al. (1975)

Lee (1977)

Lee (1977)
Neostigmine bromide

Neostigmine methylsulphate

Neostigmine methylsulphate

Neostigmine methylsulphate

Carbachol

Carbachol

Bethanecol

Pilocarpine
17

31

141

20

(1) 20

(2) 55

17

31

45

$12 \mathrm{mg}$

s.c.

31

s.c.

s.c.

s.c.

s.c.

s.c.

s.c.

s.c.

$\begin{array}{ll}8 & 25 \mathrm{iu} \\ 6 & 0.125 \mathrm{iu} / \mathrm{min}\end{array}$

$8 \quad 25$ iu and

$0.125 \mathrm{iu} / \mathrm{min}$

i.m. slow drip infusion i.m. injection and i.m. slow drip infusion

i.m.

\footnotetext{
(a) s.c. $=$ subcutancous injection (b) i.m. = intramuscular injection

(c)These results may have been influenced by the fact that all piglets were removed from the sow as they were born

ns $=$ not significantly different from controls

(English, 1969). The fact that such a high proportion of losses occurs in very early life must indicate either that many piglets are very weak at birth and/or that the conditions provided for the newborn piglet are, in general, very inadequate.
} 


\begin{tabular}{|c|c|c|c|c|}
\hline \multirow[t]{2}{*}{$\begin{array}{l}\text { Timing of } \\
\text { treatment }\end{array}$} & \multicolumn{3}{|c|}{$\begin{array}{c}\text { Decreases }(-) \text { or increases }(+) \text { relative to controls } \\
\text { (percentage changes in brackets) }\end{array}$} & \multirow[t]{2}{*}{$\begin{array}{l}\text { Other effects } \\
\text { of treatment }\end{array}$} \\
\hline & $\begin{array}{l}\text { Interval between } \\
\text { births } \\
\text { (min) }\end{array}$ & $\begin{array}{l}\text { Farrowing duration } \\
\text { (first to lasi pig) } \\
\text { (min) }\end{array}$ & $\begin{array}{l}\text { Stillbirths per } \\
\text { linter }\end{array}$ & \\
\hline $\begin{array}{l}\text { After first pig } \\
\text { After first pig }\end{array}$ & & & $\begin{array}{l}(-56.8 \%) \\
(+78.2 \%)\end{array}$ & \\
\hline $\begin{array}{l}\text { (1) As soon as milk } \\
\text { was available }\end{array}$ & - & $-78(-37.1 \%)$ & & \\
\hline $\begin{array}{l}\text { (2) After farrowing } \\
\text { had started }\end{array}$ & . & $-60(-28.6 \%)$ & & \\
\hline After fifth pig & $\begin{array}{l}-0.2(-0.7 \%) \\
\mathrm{ns}\end{array}$ & & $\begin{array}{l}-0.01(+0.8 \%) \\
\text { res }\end{array}$ & \\
\hline $\begin{array}{l}\text { After first pig } \\
\text { From first to last }\end{array}$ & & $-89(-37.2 \%) \mathrm{ns}$ & $\cdot$ & \\
\hline $\begin{array}{l}\text { pig } \\
\text { Injection after first } \\
\text { pig. Infusion }\end{array}$ & & $\begin{array}{l}-19(-7.9 \%) \mathrm{ns} \\
-150(-62.8 \%) \\
P<0.01\end{array}$ & & \\
\hline $\begin{array}{l}\text { between first and } \\
\text { last pig }\end{array}$ & & $\cdot$ & , & \\
\hline $\begin{array}{l}\text { After third or } \\
\text { fourth pig }\end{array}$ & & & $\begin{array}{l}-0.67(-76.1 \%) \\
P<0.001\end{array}$ &. \\
\hline After fifth pig & $-8.5(-29.9 \%) \mathrm{ns}$ & & $\begin{array}{l}-0.54(-73.0 \%) \\
P<0.01\end{array}$ & $\begin{array}{l}\text { Mild salivation } \\
\text { in small } \\
\text { animals }\end{array}$ \\
\hline $\begin{array}{l}\text { After first or } \\
\text { second pig }\end{array}$ & & $-135(-51.2 \%)$ & $-0.33(-54.1 \%)$ & \\
\hline After fifth pig & $\begin{array}{l}-2.3(-6.2 \%) \\
\text { ns }\end{array}$ & $\begin{array}{l}+135(+52.5 \%) \\
\text { ns }\end{array}$ & $\begin{array}{l}+0.16 \\
\mathrm{~ns}\end{array}$ & \\
\hline $\begin{array}{l}\text { After first pig } \\
\text { Ater first pig }\end{array}$ & $\begin{array}{l}-6.0(-36.4 \%) \\
-6.7(-31.6 \%) \\
P<0.05\end{array}$ & & $\begin{array}{l}(+0.32 \%) \mathrm{ns} \\
-0.05(-10.75 \%) \\
\text { ns }\end{array}$ & \\
\hline After fourth pig & & & $\begin{array}{l}-0.65(-73.5 \%) \\
P<0.001\end{array}$ & $\begin{array}{l}\text { Severe } \\
\text { salivation and } \\
\text { vomiting }\end{array}$ \\
\hline After fifth pig & $\begin{array}{l}-4.9(-17.3 \%) \\
\mathrm{ns}\end{array}$ & (1) & $\begin{array}{l}-0.61 .(-81.9 \%) \\
P<0.01\end{array}$ & $\begin{array}{l}\text { Moderate to } \\
\text { severe salivation, } \\
\text { some vomiting }\end{array}$ \\
\hline After fifth pig & $\begin{array}{l}-2.8(-9.9 \%) \\
\mathrm{ns}\end{array}$ & & $\begin{array}{l}-0.55(-75.5 \%) \\
P<0.01\end{array}$ & $\begin{array}{l}\text { Very severe } \\
\text { salivation and } \\
\text { vomiting }\end{array}$ \\
\hline
\end{tabular}

\section{CAUSES OF MORTALITY OF LIVEBIRTHS}

Deaths of liveborn piglets fall into two categories, namely, whole litter loss and the insidious loss of one or a few piglets from most litters. Most attention will be given to the latter category which is by far the most serious source of loss. 


\section{Congenital and genetic abnormalities}

Congenital and genetic abnormalities account for an average of $5 \%$ of losses in all studies ranging from $2.1 \%$ (Sharpe, 1966) to $12.3 \%$ (English and Smith, 1975). The most common causes of death in this category are atresia ani, congenital splay leg and cardiac abnormality.

\section{Disease}

While disease conditions such as agalactia in sows and scour in piglets are responsible for some losses, most studies have shown that disease as a primary factor in death accounts for only about $6 \%$ of deaths (Braude, Clarke and Mitchell, 1954; Hutchinson et al., 1954; Gracey, 1955; Sharpe, 1966; English and Smith, 1975). Taking essential precautions such as careful selection of the source of replacement stock, maintaining a high level of hygiene especially in the farrowing quarters, providing comfortable conditions for sows and piglets, arranging for adequate nutrition and adopting prophylactic or prompt therapeutic treatment to combat problems such as piglet scour, are usually effective in keeping piglet deaths from primary disease down to low levels.

\section{Starvation and overlying by the sow}

The major causes of death of baby piglets in most studies have been starvation (leading to hypoglycaemia) and overlying by the sow. Together, these two factors accounted for $74.8 \%, 79.0 \%, 50.1 \%, 73.7 \%$ and $75.9 \%$ of the deaths respectively in the studies of Braude, Clarke and Mitchell (1954), Gracey (1955), Anon (1959), Bauman, Kadlec and Powlen (1966) and English and Smith (1975). In attempts to reduce the extremely high losses suffered through starvation and overlying, efforts are required on various fronts.

Table 23.5 LIVEBIRTH LOSSES IN RELATION TO BIRTHWEIGHT

\begin{tabular}{lccc}
\hline $\begin{array}{l}\text { Birthweight } \\
\text { (g) }\end{array}$ & \% of pigs & $\begin{array}{l}\text { Mortality } \\
(\%)\end{array}$ & $\begin{array}{l}\text { Contribution to losses } \\
(\%)\end{array}$ \\
\hline Under 800 & 7.7 & 56.5 & 28.3 \\
$800-1000$ & 9.4 & 26.8 & 16.4 \\
$1000-1200$ & 16.2 & 15.5 & 16.3 \\
Over 1200 & 66.7 & 9.0 & 39.0 \\
& & & 100.0 \\
\hline
\end{tabular}

From English et al. (1977)

A very close relationship exists between birthweight and mortality (Table 23.5). It can be seen that while over $70 \%$ of the total losses are suffered by pigs of $800 \mathrm{~g}$ and over, the small proportion of pigs weighing less than $800 \mathrm{~g}$ at birth suffer extremely high losses. Piglets of low birthweight and vigour are very liable to succumb to starvation and overlying (Carroll, Krider and Andrews, 1962; English, 1969; England, 1974; English and Smith, 1975). Thus, one approach to reducing piglet losses from starvation and overlying is to attempt to increase the birthweight and vigour of the newborn piglet.

The poor insulation and inadequate temperature regulating mechanism of the newborn pig (Newland, MacMillen and Reineke, 1952; Mount, 1972) renders it very vulnerable to chilling unless an adequate thermal 
environment is provided for it. In addition, because of the very low energy reserves of the baby pig (Elsley, 1964; Elliot and Lodge, 1977) and its small stomach capacity, there is a pressing need to ensure adequate and regular nutrition. Further, since the newborn piglet constitutes only about $1 \%$ of its dam's weight and because sows can be very restless during and immediately after parturition, there is a need to ensure adequate protec. tion of the newborn piglet from overlying.

Thus, the approaches to attempting to reduce losses from starvation and overlying should include the following:

(a) Improving the birthweight and vigour of the newborn piglet.

(b) Ensuring adequate and regular nutrition.

(c) Provision of an adequate thermal environment and protection from overlying.

These three objectives are interdependent in that weaker piglets at birth are more prone to chilling, starvation and overlying. An underfed piglet is also more liable to chilling and to being overlain by the sow, while a chilled piglet is less capable of competing for a suckling position and is therefore more liable to starvation and to being overlain.

\section{ATTEMPTS TO IMPROVE THE BIRTHWEIGHT AND VIGOUR OF THE NEWBORN} PIGLET

\section{Increasing birthweight}

As already indicated, there is an inverse relationship between birthweight and losses of liveborn pigs. This is because piglets of higher birthweight lose less heat to their surroundings because of a lower surface area to weight ratio (Stanton and Carroll, 1974). Thus, they are less liable to chilling than piglets of lower birthweight. Higher birthweight pigs are also likely to have larger reserves of glycogen which is the source of energy which the piglet can utilize most effectively in early life (Dale, 1975).

Piglet birthweight can be improved by higher feed or energy intakes in pregnancy (Clawson et al., 1963; Lodge, Elsley and MacPherson, 1966a,b; O'Grady, 1967; Elsley et al. , 1969; Baker et al., 1969; Buitrago, Maner and Gallo, 1970; Lodge, 1972; Elsley and Shirlaw, 1976). The response in terms of increased birthweight is greater when daily energy intake of the sow is increased up to $30 \mathrm{MJ} D E$ than that obtained by increasing daily energy intake above this level (Elsley and Shirlaw, 1976). However, considerable increases in food or energy intake are required to bring about very modest improvements in birthweight. It has been estimated from the results of the studes cited above that to improve average piglet birthweight by only $0.1 \mathrm{~kg}$, an extra $100 \mathrm{~kg}$ (approximately $11 \mathrm{MJ} D E$ ) of a conventional UK sow diet would have to be given in pregnancy (Elsley and Shirlaw, 1976). The cost/benefit of increasing feed intake in pregnancy to improve mean piglet birthweight and piglet survival will depend on the cost of the extra food required and the value of the extra piglets likely to be saved.

Attempts to improve piglet birthweight and vigour by marked increases in feed or energy intake in very late pregnancy have produced conflicting 
488

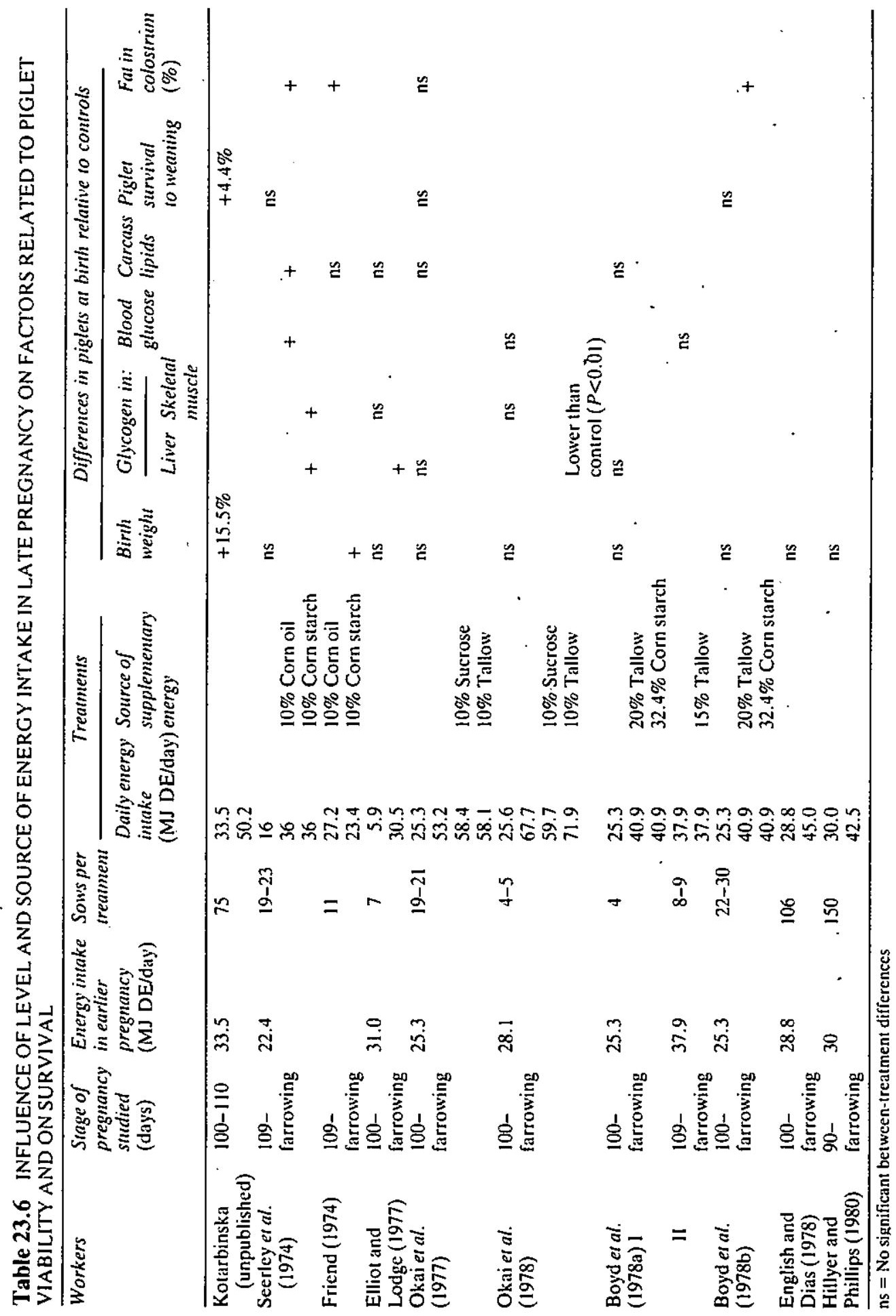


results and the relevant work is summarized in Table 23.6. Kotarbinska (unpublished data) compared normal (33.5 MJ DE) and high (50.2 MJ $\mathrm{DE})$ daily energy intakes from day 100 to day 110 of pregnancy and claimed that a $15.5 \%$ increase in birthweight and a $4.4 \%$ improvement in piglet survival was associated with the higher energy intake. However, Elliot and Lodge (1977), who compared normal energy intake (30.5 MJ $\mathrm{DE} /$ day) in the last 15 days of gestation with very low energy intake (5.9 MJ DE/day) in the same period, did not find any significant reduction in birthweight associated with the lower energy intake. However, they did find a significantly lower liver glycogen level $(P<0.05)$ to be associated with low energy intake. Other workers who have applied differential energy intakes in the last 5-15 days of gestation also failed to bring about a significant improvement in birthweight (Seerley et al., 1974; Boyd et al., 1978a,b; Okai et al., 1977, 1978; English and Dias, 1978; Hillyer and Phillips, 1980).

Other attempts to improve piglet birthweight have included the use of food additives and selection. England (1974) found that the inclusion in the sow diet for the last 30 days of gestation of 2,2-dichlorovinyl dimethyl phosphate (dichlorvos) increased birthweight in some trials but not in others. Since the heritability of birthweight is near zero (Craig, Norton and Terrill, 1956) there is little hope of effecting improvement in this trait by selection. Thus, it appears to be very difficult to bring about worthwhile improvements in piglet birthweight.

Variation in piglet birthweight is just as important as birthweight per se, if not even more so, in relation to chances of survival (English, 1969; Fahmy and Bernard, 1971; English and Smith, 1975) as indicated in Table 23.7. It can be seen that litters with high mean birthweight but with high variation in birthweight within litters suffered as high mortality as both low birthweight litter groups. The lowest mortality rate $(13.7 \%)$ was in the high birthweight group with low within-litter variation in birthweight.

The competition for possession of a suckling position, and therefore for nutrition, can be severe and small piglets in an uneven litter (in terms of birthweight) are at a severe physical disadvantage. Within-litter birthweight variation tends to be reduced with crossbreeding and to increase with advancing parity but, apart from these relationships, there is no known way of influencing this character so as to obtain more uniform

Table 23.7 VARIATION IN BIRTHWEIGHT WITHIN LITTERS IN RELATION TO MORTALITY OF LIVEBIRTHS

\begin{tabular}{|c|c|c|c|c|c|c|}
\hline \multirow[t]{2}{*}{ Litter groups } & \multicolumn{3}{|c|}{ High birthweight } & \multirow{2}{*}{$\begin{array}{l}\text { Mean } \\
\text { birthweight } \\
\text { (g) }\end{array}$} & \multicolumn{2}{|c|}{ Low birthweigh } \\
\hline & $\begin{array}{l}\text { Mean } \\
\text { birthweight } \\
(\mathrm{g})\end{array}$ & $\begin{array}{l}\text { Within-litter } \\
\text { standard } \\
\text { deviation in } \\
\text { birthweight }\end{array}$ & $\begin{array}{l}\text { Mortality' } \\
(\%)\end{array}$ & & $\begin{array}{l}\text { Within-linter } \\
\text { standard } \\
\text { deviation in } \\
\text { birlhweight }\end{array}$ & $\begin{array}{l}\text { Mortality } \\
(\%)\end{array}$ \\
\hline $\begin{array}{l}\text { High standard } \\
\text { deviation }\end{array}$ & 1397 & 277 & 20.1 & 1148 & 268 & 19.9 \\
\hline $\begin{array}{l}\text { Low standard } \\
\text { deviation }\end{array}$ & 1374 & 154 & 13.7 & 1129 & 177 & 19.3 \\
\hline
\end{tabular}

(a) Overall average of means for within-litter standard deviation in birthweight for each litter size group. Data in each of four subgroups based on 78 litters and 895 livebirths.

From English and Smith (1975) 
litters at birth. The only effective way to achieve more uniform birthweights within litters is to artificially create such litters very soon after birth by crossfostering between simultaneously farrowed litters. This approach will be discussed in a later section.

\section{Improving energy reserves and piglet vigour at birth}

Several attempts have been made to increase the energy reserves of piglets at birth by manipulations of nutrition in very late pregnancy and the results of these trials are summarized in Table 23.6. It has already been mentioned that Elliot and Lodge (1977) found significantly lower glycogen levels $(P<0.05)$ at birth in piglets born to sows on a low energy intake in the last 15 days of gestation. When Seerley et al. (1974) supplemented a basal diet with either corn starch or corn oil from the 109th day of gestation so as to more than double the sows' energy intake in this period, significant increases $(P<0.05)$ in glycogen content of both the liver and the longissimus dorsi muscle of newborn piglets was associated with the corn starch supplemented treatment. Supplementation of the basal diet with corn oil resulted in significant increases in both body fat and blood glucose at birth and there were some indications (although not statistically significant) of improved piglet survival.

Supplementation of a basal diet (25.3 MJ DE/day) with either corn starch or stabilized tallow to provide $40.9 \mathrm{MJ} \mathrm{DE} /$ day from day 100 of pregnancy to parturition did not result in any apparent differences in piglets at birth (Boyd et al., 1978b), although the fat content of the colostrum of sows supplemented with tallow was significantly higher than in controls $(P<0.05)$. In another experiment Boyd et al. $(1978 \mathrm{a})$ failed to demonstrate any significant differences in liver glycogen, or in carcass fat of newborn piglets from sows supplemented with either corn starch or tallow from day 100 of pregnancy relative to piglets from sows receiving a much lower energy intake from a control diet in this period.

Other studies by Okai et al. (1977), Okai et al. (1978), Boyd et al. (1978b), Curtis, Heidenreich and Foley (1965), and Reedy et al. (1966) involving various manipulations of nutrition from day 100 of gestation to parturition failed to produce a consistent response in terms of increased energy reserves or indices of improved viability in piglets at birth.

Thus, while increased energy intake in the last 1-2 weeks of pregnancy has given promise in some trials of more viable pigs at birth, responses obtained in general have been very inconsistent and, on the basis of existing evidence, there would appear to be no sound basis for making any recommendations for commercial practice regarding manipulations of nutrition in late pregnancy likely to improve viability of newborn piglets.

However, many of the trials which have examined the effects of higher energy intake or of particular energy supplements in late pregnancy have been carried out with relatively small numbers of animals (see Table 23.6). Other trials which have involved larger numbers have merely examined the effect of higher energy levels in late pregnancy on piglet birthweight (English and Dias, 1978; Hillyer and Phillips, 1980), and have failed to 
monitor other indices of piglet viability or piglet survival. Thus, there is a need for a large scale comprehensive experiment to examine the effects of differential energy intakes in late pregnancy on all important indices of piglet viability at birth and on piglet survival to weaning.

One important provision for improving the vigour of the newborn piglet which is implemented widely in practice is that of crossbreeding. It is well established that for commercial production a policy of crossbreeding should be operated because of the important influence of heterosis on piglet vigour at birth and on survival (Fredeen, 1957; Smith and King, 1964).

\section{Improving vigour at birth: general position}

As far as the problems of low and variable piglet birthweights and inadequate vigour at birth are concerned, it is clear from the foregoing reviews that these problems can be resolved only to-a small degree through breeding strategy and manipulations of prenatal nutrition. Research work related to increasing piglet vigour at birth must be continued and given adequate support. However, since the problems of inadequate piglet vigour at birth and variation in birthweight cannot, as yet, be resolved effectively by amendments of prenatal management, the present onus in commercial practice is on postnatal management to recognize piglets at risk from these factors and to take all necessary precautions, within the limits of economic and practical feasibility, to maximize the survival chances of these disadvantaged and under-privileged piglets.

\section{IMPROVING THE CHANCES OF ADEQUATE AND REGULAR NUTRITION}

Much research and development effort has been devoted to improving the opportunities for adequate and regular nutrition of each viable piglet born. One overriding consideration in these studies must be the fact that most piglets which ultimately die from malnutrition around 2-3 days of age are actually moribund almost from the moment of birth because of their inability, or reduced ability, to obtain adequate and regular nutrition mainly because of the very competitive situation which prevails at suckling (English, 1969). Thus, measures to improve survival of such disadvantaged and under-privileged piglets must be implemented at parturition or immediately afterwards. Studies related to improving opportunities for adequate and regular nutrition have involved the following approaches.

(a) Conservation of the newborn piglet's scarce energy reserves.

(b) Studies on sow rearing capacity and fostering strategy.

(c) Studies related to minimizing the effects of agalactia.

(d) Provision of supplementary feeding to newborn piglets.

(e) Artificial rearing of piglets surplus to rearing capacity.

(f) Synchronized farrowing and its supervision. 


\section{Conservation of the newborn piglet's scarce energy reserves}

Reference has already been made to the comparatively low energy reserves (Elsley 1964; Elliott and Lodge, 1977) and the poor insulation and temperature regulating mechanism of the newborn pig (Newland, MacMillen and Reineke, 1952; Mount, 1972). Estimates of the environmental temperature requirement of the newborn pig vary from $32-36^{\circ} \mathrm{C}$, the smaller pigs requiring a higher temperature (Mount, 1972).

Provision of a perfect thermal environment in the farrowing pen is vitally important in minimizing heat loss so as to prevent chilling and to ensure sufficient energy is available to help each piglet to obtain and retain a functional feeding place at the udder under the stress of severe competition from litter mates. It is important for supplementary heating, without draughts, to be provided in the farrowing pen at the site of birth and adjacent to the udder to ensure, as far as possible, that the newborn piglet will have an adequate thermal environment from birth. Piglets have a natural inclination to spend a high proportion of their first 24 hours of life adjacent to the udder (Titterington and Fraser, 1976; Wilkinson and English, 1981), so that supplementary heating should be concentrated in the side creep areas outside the confines of the farrowing crate at least in the first 24 hours of life.

\section{Studies on sow rearing capacity and fostering strategy}

Sow rearing capacity refers to the number of functional teats exposed to piglets at nursing. This aspect has been reviewed extensively by English, Smith and MacLean (1977). To increase the opportunities for adequate and regular nutrition from birth and to cater for a large number of piglets per litter it is very important to ensure that selected gilts have adequate 'rearing capacity'. Gilts should have at least 14 well developed, evenly spaced teats and the lateral distance between equivalent pairs of teats should not be excessive so as to increase the chances that all teats on the lower row will be adequately exposed to piglets when the sow is in the recumbent position at nursing. Older sows, with more pendulous udders, experience greater difficulty in exposing the more posterior teats on the lower row at nursing (English, Smith and MacLean, 1977). It is important that such problems are detected promptly so as to guide both fostering and culling strategy.

Fostering strategy should cater not only for piglets which are surplus to 'rearing capacity' (supernumerary piglets) but should also have the objective of reducing variation in birthweight within litters. Crossfostering between simultaneously farrowed litters so as to have all the small piglets on one sow and the larger ones on another sow has been shown to be effective in effecting significant reductions in piglet losses (English, Smith and MacLean, 1977). It is important to correct problems of variation in birthweight within litters and of supernumerary piglets very soon after piglets have had the opportunity to obtain adequate colostrum from their own dam. 
Agalactia refers to complete lactational failure while hypogalactia is the term used to describe partial lactational failure. It is part of the complex condition of MMA (M = mastitis or inflammation of the udder, $M=$ metritis or inflammation of the womb and $\mathrm{A}=$ agalactia). The MMA syndrome can involve metabolic, bacterial and hormonal factors with stress playing a part (Ringarp, 1960; English, Smith and Maclean, 1977).

Since its main effect is loss of milk in the first three days after farrowing, the condition contributes to piglet losses from starvation and, while research findings do not appear to have provided a basis for effective preventative measures, some positive steps can be taken in practice to minimize the worst effects of the condition.

In many cases, elevated body temperature is associated with the condition (English, 1969; Bugeac, 1971) so that regular monitoring of sow rectal temperature in the first 2-3 days after farrowing can be effective in helping to detect some cases of agalactia promptly. Once detected, the course of treatment found to be effective in resolving similar cases in the past must be applied promptly to ensure that full milk production is restored as quickly as possible before piglets begin to suffer unduly from malnutrition. This usually takes the form of antibiotic therapy sometimes accompanied by oxytocin (Martin and Threfall, 1970). If agalactia is not detected until other signs, such as loss of appetite by the sow or restlessness or loss of body condition in piglets, become evident then it is usually much more difficult to resolve the condition quickly so as to minimize the degree of malnutrition suffered by piglets. In situations where the condition is difficult to resolve, alternative prompt provision for piglets such as fostering or artificial rearing must be made so as to minimize losses from starvation.

It is possible that a form of agalactia can be induced by heat stress through having a high ambient temperature in the farrowing house as suggested by Fraser (1970). Thus, while it is extremely important to provide a very warm environment for newborn piglets in the farrowing house, the lactating sow is likely to benefit from much cooler conditions.

\section{Provision of supplementary feeding to newborn piglets}

The provision of supplementary milk substitute to suckling piglets may be justified to improve the nutrition of individual piglets in larger litters which experience difficulty in commanding a suckling position regularly and such provision may also be justified to provide for piglets on sows suffering from agalactia or hypogalactia.

However, there appears to be no published work on such a practice. English, Dawson and Ritchie (1980, unpublished data) evaluated the use of such liquid supplements of piglet milk substitute for litters in the first three days of life. Although considerable quantities of liquid milk substitute were consumed by some litters, no improvement in piglet survival was observed although supplemented piglets were significantly heavier $(P<0.05)$ at 7 days of age. However, piglet mortality in this study was very 
low, being $5.5 \%$. There appears to be a need to evaluate this practice on a wider basis. Progressive commercial units are using it, especially for very large litters, and claim to be obtaining a useful response. Such an approach may well be preferable to artificial rearing of supernumerary piglets in situations where such piglets cannot be fostered to other sows with spare rearing capacity.

Other approaches to improving the energy stores and nutrition of suckling pigs have involved the feeding of colostrum or milk substitute to weakly pigs by stomach tube and the administration of glucose to newborn pigs either orally or by peritoneal injection. MacPherson and Jones (1976) reported a slight improvement in survival following the intraperitoneal administration of $2 \mathrm{~g}$ glucose $(10 \mathrm{ml}$ of a $20 \%$ solution $)$ to newborn piglets.

\section{Artificial rearing of piglets surplus to rearing capacity}

Many attempts have been made to develop suitable artificial rearing systems for piglets. Some systems were designed for rearing hysterectomyderived pigs as a basis for producing specific pathogen-free (SPF) pigs or for rearing entire litters of pigs from birth for other specialized reasons (Young and Underdahl, 1953; Lecce and Matrone, 1960; Betts, Lamont and Littlewort, 1960). Other artificial rearing systems were designed to rear piglets surplus to sow rearing capacity from within a few hours of birth with the remainder of the litter being reared naturally (Dyrendahl et al., 1953; Braude, Clarke and Mitchell, 1954; English and Smith, 1976; Scott and Pringle, 1976; Scott, 1981). The ease of operation and efficiency of artificial rearing systems has varied, some being fairly successful. However, to be effective and useful in commercial practice, artificial rearing systems must be almost fully automated so as to reduce labour requirement. In turn, automated systems must be very reliable so as to ensure that piglets receive adequate and regular nutrition. As yet, no automated artificial rearing system has been developed which is suitable and reliable for use in commercial practice. Until a suitable system is developed, provision for supernumerary piglets must be made by fostering or by supplementary feeding within the litter. In fact, if these latter approaches can be exploited to cater adequately for supernumerary piglets then this is likely to be very advantageous in terms of ease and cost of operation relative to an artificial rearing system.

\section{Synchronized farrowing and its supervision}

It is clear that the basic factors which predispose to malnutrition and ultimate death from this cause in the great majority of cases operate almost from the moment of birth. Thus, it is very important that strategic measures are taken to increase the chances of regular nutrition for each viable piglet born from very soon after birth. In addition, sows can be very restless during the parturition process and during this time, as piglets explore the area of their pen almost at random, they are very vulnerable to death from overlying by the sow (English, 1969). 
It is widely accepted that supervision of farrowing and provision of strategic assistance to vulnerable piglets is very cost effective in increasing piglet survival (England, 1966). Supervision of farrowing can be better justified, in economic terms, if a batch system of farrowing is practised (English, 1978) and the use of chemicals such as analogues of prostaglandin $\mathrm{F}_{2 \alpha}\left(\mathrm{PGF}_{2 \alpha}\right)$ have been shown to be fairly effective in inducing parturition at specific times to facilitate supervision of a batch of farrowing sows (Ash and Heap, 1973; Downey et al., 1976; Hammond and Carlyle, 1976; English et al., 1977; Walker, 1977). The latter three groups of workers used an injection of $175 \mu \mathrm{g}$ of a $\mathrm{PGF}_{2 \alpha}$ analogue (Cloprostenol, ICI 80996) between days 111 and 116 of pregnancy and found that between $66 \%$ and $80 \%$ of farrowings took place within 24-34 hours following the injection.

While analogues of $\mathrm{PGF}_{2 \alpha}$ are very effective in inducing and synchronizing farrowing of a group of sows, certain precautions must be exercised in their use. Inducement of farrowing implies premature birth to a varying degree. It appears that liver glycogen content increases 15 -fold during the last 15 days of foetal life (Elliot and Lodge, 1977) and inducement of farrowing 1-3 days early is likely to be associated with lower energy reserves in newborn piglets. Both Downey et al. (1976) and Walker (1977) found that litters induced 1-3 days early relative to controls had lower birthweight and lower survival rates. English et al. (1977), despite applying very intensive measures of care to the piglets from induced farrowings, failed to improve survival relative to controls. Piglets induced to farrow on day 115 (average gestation for the herd) had better survival than controls whereas those induced to farrow one and two days early had progressively poorer survival. Hammond and Carlyle (1976) have also drawn attention to the dangers of premature farrowing.

Thus, while induced farrowing using analogues of $\mathrm{PGF}_{2 \alpha}$ provides a very useful means of achieving batch farrowing, the risks of inducing farrowing too prematurely must be recognized. However, the technique is being applied in commercial practice successfully, particularly to induce parturition in those sows which have failed to farrow by the end of the average gestation period for the herd.

Research work is in progress examining the possibility of achieving synchronized farrowing by prolonging gestation slightly through the use of progestagens (Gooneratne et al., 1979; Varley and Brooking, 1981).

When farrowings are being supervised, then practices known to be effective in improving piglet survival include:

(a) placing weaker piglets under the heat source and assisting them to suckle;

(b) feeding very weak piglets with sow or cow colostrum by stomach tube;

(c) cross-fostering piglets between simultaneously farrowea litters so as to equalize, as far as possible, birthweights within litters;

(d) artificial rearing of piglets which are surplus to the rearing capacity of their dam after the technique of fostering has been exploited to the fullest extent;

(e) regular monitoring of sow health and prompt detection and treatment of any condition likely to lead to agalactia. 
These practices have been part of the systems operated by England, Chapman and Bertun (1961), and by English, Smith and MacLean (1977) which were effective in achieving very high piglet survival rates.

An essential part of any system which sets out to achieve high piglet survival rate is availability of skilled, knowledgeable and well motivated stockmen who are given sufficient time and opportunity to exercize their skills.

\section{REDUCING LOSSES FROM OVERLYING}

Various approaches have been adopted for reducing losses from overlying (English, Smith and MacLean, 1977). The risk of overlying is influenced by the relative activity of the dam and her piglets and by the wellbeing and relative contentment of the latter. Factors which help to reduce the restlessness of piglets include measures to ensure their adequate nutrition as discussed previously (p.491). Associated with this objective is the provision of a very comfortable creep area within the farrowing pen, preferably situated at each side adjacent to the udder at least for the first 24 hours of life. The more adequate the nutrition of the piglets and the more comfortable they are, the less restless they tend to be.

Sow activity tends to be particularly high during parturition and around the regular feeding periods (English, 1969) with risks of overlying being correspondingly high at these times. In commercial units where these high risk periods are recognized and piglets are enclosed in the creep areas during these periods, the incidence of overlying appears to have been reduced.

In view of the peaks of sow restlessness which prevail in a farrowing house around the regular twice daily sow feeding times, alternative feeding strategies such as once daily feeding are worthy of study. In some situations adoption of ad libitum feeding during at least the early part of lactation has been shown to remove the peaks of sow activity, reduce its degree and result in improved piglet survival (English, 1969).

The work routine in the farrowing house is also worthy of study. Where sows are fed on a regular basis it is likely to be desirable to carry out all piglet management tasks while the sows are feeding. Such a measure would be likely to result in a much more peaceful situation for the remainder of the day in what is, in effect, a nursery area.

Most research and development work in relation to reducing losses from overlying has centred on the farrowing pen and crate. Robertson et al. (1966) demonstrated the benefits of providing a well designed farrowing pen incorporating a farrowing crate. Further work has been devoted to particular aspects of design of the farrowing pen and crate in relation to making the whole arrangement as 'fail safe' as possible in relation to risk of overlying, to ensuring maximum comfort for piglets and for the sow and to effecting labour economy in its operation.

The efforts towards development of more effective farrowing accommodation have been reviewed by English, Smith and MacLean (1977). Aspects of particular importance in relation to minimizing losses from overlying include the following: 
(a) Arranging an atractive and comfortable creep area for the piglets.

(b) Providing an adequate floor surface to allow good mobility of the piglets and ensure good foothold by the sow.

(c) Provision of a farrowing crate designed in such a way as to help control the descent of the sow as she lies from the standing position. It is very important that the design obliges the sow to lie down carefully on to her belly first before rolling over on to either side (English, Smith and MacLean, 1977).

\section{OVERALL STRATEGY FOR REDUCING PIGLET LOSSES IN PRACTICE}

The information resulting from research and development work related to piglet viability and prevention of losses has been synthesized into an 'advisory package' and this has been applied in practice to a varying degree in commercial breeding units. This 'package' incorporates advice on the provision of suitable farrowing accommodation, the maintenance of good herd health status, good hygiene, and intensive care strategy in catering for the needs of the farrowing sow and her newborn piglets and on the basis of sound sow and litter management in lactation. In commercial units where such advice is applied rigorously, losses of liveborn pigs have been reduced to around 5\% (England Chapman and Bertun, 1961; English, Smith and Maclean, 1977). In view of the difficulty of eliminating the incidence of genetic and congenital abnormalities, it is probably unrealistic in practice to expect losses of livebirths to be reduced much below this level.

\section{FAILURE TO APPLY EXISTING KNOWLEDGE IN PRACTICE}

Although some commercial units are achieving high piglet survival rates of 95\% or over, even with 11 livebirths or more per litter (English, Smith and Maclean, 1977), and about $20 \%$ of recorded herds in the UK are achieving survival rates of between 90 and $95 \%$ with 10.5 or over livebirths per litter, the majority of pig units are still experiencing between 10 and $20 \%$ losses of livebirths in practice (Meat and Livestock Commission, 1980). This is illustrated in Table 23.8 which summarizes the performance of herds recorded by the Meat and Livestock Commission in the UK.

Table 23.8 BETWEEN-HERD DISTRIBUTION IN PRE-WEANING MORTALITY OF LIVEBIRTHS. (HERDS AVERAGING 10.5 OR OVER LIVEBIRTHS PER LITTER)

\begin{tabular}{lcc}
\hline $\begin{array}{l}\text { Livebirth } \\
\text { losses }\end{array}$ & \multicolumn{2}{c}{ Herds } \\
\cline { 2 - 3 }$(\%)$ & Number & Per Cent \\
\hline $0-5$ & 3 & 1 \\
$5-10$ & 42 & 19 \\
$10-15$ & 102 & 47 \\
$15-20$ & 58 & 27 \\
Over 20 & 13 & 6 \\
\hline
\end{tabular}

From Meat and Livestock Commission (1980) 
It is likely that on the great majority of units high piglet losses are still being experienced because existing knowledge is not being applied adequately in practice. Achieving high piglet survival is dependent on many factors and these must be catered for in establishing a sound farrowing and rearing system as illustrated in Figure 23.2. Failure to make adequate provision for all requirements will result in a less reliable system and higher piglet losses.
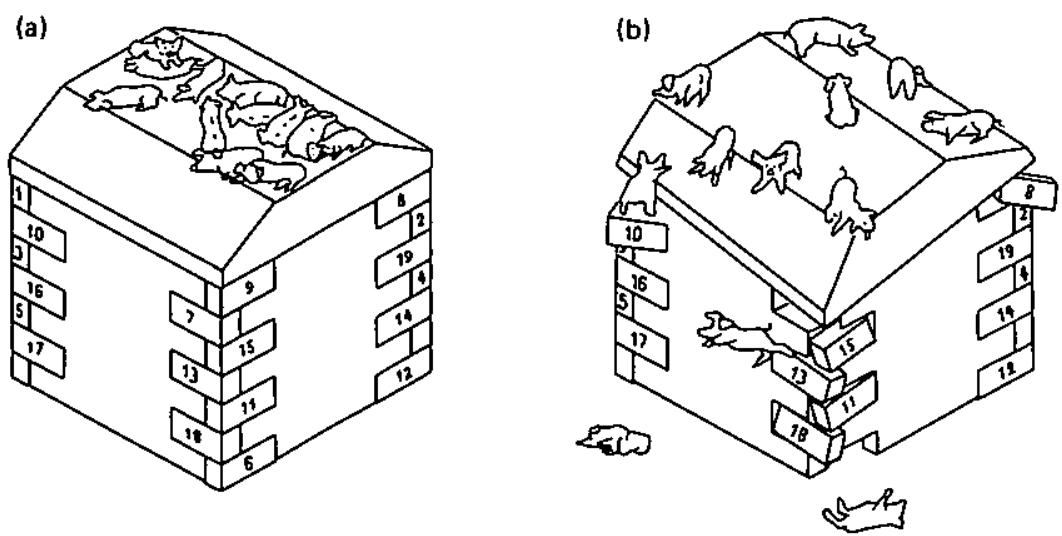

Figure 23.2 An analogy of contrasting piglet rearing systems. (a) A sound system with all vital components provided and all piglets firmly established. (b) An unsound system with one or two vital components missing or inadequately provided. This puts more piglets at risk and increases pigiet losses

On the majority of pig units, farrowing accommodation combined with the farrowing and lactation management system, tends to cater only for the best $85 \%$ or so of liveborn piglets. They fail to cater adequately for the remaining $15 \%$ of the smaller and weaker piglets. Important components of such a system likely to be most defective are faulty design of the farrowing pen and crate, inadequate thermal environment and the failure to apply appropriate intensive care strategy to the weaker and more vulnerable piglets at farrowing Most pig keepers have failed to realize that the exact stage at which piglets die is not so important as is the point at which they 'start to die'. The point has already been made that most piglets dying from malnutrition will die on the second or third day of life but most become moribund almost from the moment of birth. There is a general failure to assist weakly piglets at birth at a sufficiently early stage. Other crucial problems which tend not to be detected and treated with sufficient promptness include dystocia and agalactia.

\section{NEED FOR ROUTINE MONITORING OF EVENTS DURING AND IMMEDIATELY AFTER PARTURITION}

The basic reason why there is general failure to detect and attempt to rectify problems associated with dystocia, weakness at birth and agalactia promptly may be related to the non-routine incidence of such events. It is likely that stockpersons deal much more competently with routine tasks 
than they do with events that are unpredictable and occur in a random manner. If such an hypothesis is correct, it calls for a strategy of much more routine monitoring of events during and immediately after parturition being put into operation on commercial breeding units.

\section{Supplementary feeding of the litter}

Aspects of supplementary feeding in the immediate postnatal period to increase energy reserves and to improve nutrition of the underprivileged and disadvantaged piglets have already been reviewed (p.493).

'Creep' feeding refers to the provision of supplementary dry feed to the suckling litter and it has two main purposes. The first is to augment the sow's milk supply which is inadequate for maximum growth especially after three weeks of age. It is also required to accustom suckling piglets to dry feed so as to encourage increased consumption by weaning in an attempt to reduce growth checks and digestive disturbances at this stage.

The practice of creep feeding was initiated when weaning took place at 6-8 weeks of age. With the sow's milk yield declining after three weeks of lactation, sound creep feeding practice was found to be essential to supplement the declining milk yield after three weeks so as to ensure reasonable growth to weaning and acceptable weaning weight. With the advent of very early weaning at $2-3$ weeks of age it is perhaps more difficult to justify the practice of creep feeding. However, the justification of the practice of creep feeding on early weaning systems would be increased if it could be demonstrated to stimulate an earlier development of the mature digestive enzyme system. This may help to reduce the effects of the malabsorption syndrome common at weaning (Kenworthy, 1967) and to reduce growth checks (Okai, Aherne and Hardin, 1976) and post-weaning mortality (English, 1980).

The digestive system of the baby pig is equipped to deal only with lactose, casein and easily digested fats. The ability of the digestive system to deal with more complex carbohydrates, non-milk sugars and with proteins other than casein develops slowly, but there is evidence that earlier development of sucrase, maltase, amylase and trypsin activity can be induced by encouraging earlier consumption of non-milk sugars, starch and protein (Aumaitre and Rerat, 1966; Aumaitre, 1972).

The practice of creep feeding, using a diet that would be both acceptable and digestible to young pigs (Fowler, 1980), might therefore be expected to stimulate an earlier development of the mature digestive enzyme system and result in a reduced growth check following early weaning. The work of Friend, Gorrill and Maclntyre (1970) and that of Okai, Aherne and Hardin (1976) did not produce strong evidence of such an effect but the work of English, Robb and Dias (1980) indicated that a sound creep feeding system using a highly digestible diet, not only resulted in improvements in piglet growth during the suckling period, but also led to improved feed intake and performance following weaning. The reason for the failure of creep feeding to improve post-weaning performance in the work of Friend, Gorrill and MacIntyre (1970) and of Okai, Aherne and Hardin (1976), in which weaning took place at either three or five weeks of age, might be 
associated with the relatively small creep feed intakes achieved in their work relative to that achieved by piglets in the work of English, Robb and Dias (1980). In the latter work, the highly digestible diet used was in meal form and was offered from one week of age to pigs which were to be weaned at four weeks of age. The creep feed was made readily available in shallow troughs and uneaten feed was discarded and fresh feed added twice daily. Although this work demonstrated that a soundly based and well managed creep feeding strategy could be beneficial for pigs to be weaned at four weeks of age, the benefits of creep feeding for pigs to be weaned at earlier ages have not yet been demonstrated.

The essential features of a sound creep feeding system would appear to be as follows:

(a) An acceptable and digestible diet.

(b) A suitable form of diet (a flaky meal or small pellet in preference to finely ground material).

(c) A suitable feeder which makes the creep feed readily visible and available.

(d) Suitable placement of the creep feeder within the pen to minimize risk of fouling.

(e) Feeding of creep on a 'little and often' basis with strict attention to cleanliness of the system, frequent and regular removal of uneaten creep and replacement with fresh material.

\section{Need for more research}

The point has already been made that much of the inefficiency associated with piglet rearing is due to failure to apply existing knowledge in practice. However, there is considerable scope for further research on many aspects relating to piglet survival and growth, and the most crucial area in which further research effort should be concentrated is that of improvement of viability of the newborn pig. Piglets of low birthweight and those otherwise weak at birth are most demanding in terms of the conditions which must be provided and the skill and effort involved in the intensive care strategy necessary to ensure their survival.

\section{References}

ANON (1959). A survey of the incidence and causes of mortality in pigs. 1. Sow survey. Vet. Rec. 71, 777-786

ASDELL, S.A. and WILLMAN, J.P. (1941). The causes of stillbirth in swine and an attempt to control it. J. agric. Res. 63, 345-353

ASH, R.W. and HEAP, R.B. (1973). The induction and synchronisation of parturition in sows treated with I.C.I.79,939, an analogue of PGF $2 \alpha . J$. agric. Sci., Camb. 81, 365-368

AUMAITRE, A. (1972). Development of enzyme activity in the digestive tract of the suckling pig: nutritional significance and implications for weaning. Wld Rev. Anim. Prod. 8, 54-68 
AUMAITRE, A. and RERAT, A. (1966). Unpublished data cited by Aumaitre, A. (1972). Wld. Rev. Anim. Prod. 8, 54-68

BAKER, D.H., BECKER, D.E., NORTON, H.W., SASSE, C.E., JENSEN, A.H. and HARMON, B.G. (1969). Reproductive performance and progeny development in swine as influenced by feed intake during pregnancy. $J$. Nutr. 97, 489-495

BAUMAN, R.M., KADLEC, J.E. and POWLEN, P.A. (1966). Some factors affecting death loss in baby pigs. Purdue Univ. Agric. Exp. Sin. Res. Bull. 810

BETTS, A.O.. LAMONT, P.H. and LITTLEWORT, M.C.G. (1960). The production by hysterectomy of pathogen-free, colostrum-deprived pigs and the foundation of a minimal-disease herd. Vet. Rec. 72, 461-468

BILLE, N., NIELSEN, N.C., LARSEN, J.L. and SVENDSEN, J. (1974). Preweaning mortality in pigs. 2. The perinatal period. Nord. VetMed. 26, 294-313

BOYD, R.D., MOSER, B.D., PEO, E.R. and CUNNINGHAM, P.J. (1978a). Effect of energy source prior to parturition and during lactation on tissue lipid, liver glycogen and plasma levels of some metabolites in the newborn pig. J. Anim. Sci. 47, 874-882

BOYD, R.D., MOSER, B.D., PEO, E.R. and CUNNINGHAM, P.J. (1978b). Effect of energy source prior to parturition and during lactation on piglet survival and growth and on milk lipids. J. Anim. Sci. 47, 883-892

BRAUDE, R., CLARKE, P.M. and MITCHELL, K.G. (1954). Analysis of the breeding records of a herd of pigs. J. agric. Sci. 45, 19-27

BRENNER, K.V., SCHULZE, H. and GURTLER, H. (1978). Application of oxytocin during parturition-impact on the processes of birth in the sow and on glucose and lactate levels in blood plasma or blood of newborn piglets. Mh. VetMed. 33, 304-308

BUGEAC, T. (1971). Observations and research on the metritis-mastitisagalactia syndrome in sows and diarrhoea in newborn piglets. Revta Zootech. Med. Vet. 21, 50-58

BUITRAGO, J., MANER, J.H. and GalloO, J.T. (1970). Effect of gestation energy level on reproductive performance. J. Anim. Sci. 31, 197 (Abstract)

CARMICHAEL, W.J. and RICE, J.B. (1920). Variations in farrow: with special references to the birthweight of pigs. Illinois Agric. Exp. Stn Bull. 226, $67-95$

CARROLL, W.E., KRIDER, J.L. and ANDREWS, F.N. (1962). Swine Production. Third Edition. p.137. New York, McGraw-Hill Book Company

ClAWSON, A.J., RICHARDS, H.L., MATRONE, G. and BARRICK, E.R. (1963). Influence of level of total nutrient and protein intake on reproductive performance in swine. J. Anim. Sci. 22, 662

CRAIG, J.V., NORTON, H.W. and TERRILl, S.W. (1956). A genetic study of weight at five ages in Hampshire swine. J. Anim. Sci. 15, 242-256

CURTIS, S.E. (1974). Responses of the piglet to perinatal stressors. J. Anim. Sci. 38, 1031-1036

CURTIS, S.E., HEIDENREICH, C.J. and FOLEY, C.W. (1965). Effect of late prepartum glucose loading of sows on birthweight in pigs. J. Anim. Sci. 24, 915 (Abstract)

DALE, H.E. (1975). Energy metabolism. In Duke's Physiology of Domestic Animals. 8th Edition. Ithaca and London, Comstock Publishing Association 
DAWES, G.S., JACOBSON, H.N., MOTT, J.C., SHELLEY, H.J. and STAFFORD, A. (1963). The treatment of asphyxiated, mature foetal lambs and rhesus monkeys with intravenous glucose and sodium carbonate. J. Physiol. Lond. 169, 167-184

DENAMUR, D. (1965). The hypothalamo-neurohypophyseal system and the milk ejection reflex. Dairy Sci. Abstr. 27, 193-244

DOWNEY, B.R., CONLON, P.D., IRVINE, D.S. and BAKER, R.D. (1976). Controlled farrowing program using a prostaglandin analogue, AY24,655. Can. J. Anim. Sci. 56, 655-659

DUNNE, H.W. and LEMAN, A.D. (1975). Diseases of Swine. 4th Edition. Ames, Iowa, Iowa State University Press

DYRENDAHL, S., SWAHN, O., BJÖRCK, G. and HELLVING, L. (1953). Artificial raising of baby pigs. Acta Agric. Scand. 3, 334-354

ELLIOT, J.I. and LODGE, G.A. (1977). Body composition and glycogen reserves in the neonatal pig during the first 96 hours postpartum. Can. $J$. Anim. Sci. 57, 141-150

ELSLEY, F.W.H. (1964). The physiological development of the young pig. Annls Zootech. 13, 75-84

ELSLEY, F.W.H. and SHIRLAW, D.W.G. (1976). Aspects of the energy nutrition of sows. 27th Annual Meeting of the E.A.A.P., Zurich

ELSLEY, F.W.H., BANNERMAN, M., BATHURST, E.V.J., BRACEWELL, A.G., CUNNINGHAM, J.M.M., DODSWORTH, T.L., DODDS, P.A., FORBES, T.J.. and LAIRD, R. (1969). The effect of level of feed intake in pregnancy and in lactation uipon the productivity of sows. Anim. Prod. 11, 225-241

ENGLAND, D.C. (1966). Saving the pig crop. Summary Article. Oregon State University

ENGLAND, D.C. (1974). Husbandry components in prenatal and perinatal development in swine. J. Anim. Sci. 38, 1045-1049

ENGLAND, D.C., CHAPMAN, V.M. and BERTUN, P.L. (1961). Relationship between birthweight and volume of milk consumed by artificially reared baby pigs. Proceedings of the Western Section, American Society of Animal Production, 12, 1-5

ENGLISH, P.R. (1969). Mortality and variation in growth of piglets: A study of predisposing factors with particular reference to sow and piglet behaviour. PhD Thesis. University of Aberdeen

ENGlish, P.R. (1978). Benefits of batch farrowing. Pig Fmg. 26, 35-37

ENGlish, P.R. (1980). Establishing the early weaned pig. Proc. Pig Vet. Soc., 7, 29-37

ENGLISH, P.R. and DIAS, M.F.M. (1978). Effect of feeding level of the sow in late pregnancy on piglet birthweight. Research, Investigation and Field Trials, North of Scotland College of Agriculture, 1977-78, 57-58

ENGLISH, P.R. and SMITH, W.J. (1975). Some causes of death in neonatal piglets. Vet. Ann. 15, 95-104

ENGLISH, P.R. and SMITH, W.J. (1976). Experiments on complementary artificial. rearing of piglets. 1. The need for artificial rearing. $\mathrm{Fm}$. Building Prog. 45, 5-7

ENGLISH, P.R., DAWSON, I. and RITCHIE, R.M. (1980). Unpublished data

ENGLISH, P.R., ROBB, C.M. and DIAS, M.F.M. (1980). Evaluation of creep feeding using a highly digestible diet for litters weaned at 4 weeks of age. Anim. Prod. 30, 496 (Abstract) 
ENGLISH, P.R., SMITH, W.J. and MACLEAN, A. (1977). The Sow:Improving her Efficiency. 311 pages. Ipswich, Suffolk, Farming Press Ltd.

ENGLISH, P.R., HAMMOND, D., DAVIDSON, F.M., SMITH, W.J., SILVER, C.L., DIAS, M.F.M. and MACPHERSON, R.M. (1977). Evaluation of an induced farrowing system using cloprostenol, (I.C.I. 80996) a synthetic analogue of prostaglandin $\mathrm{F}_{2 \alpha}$. Anim. Prod. 24, 139-140 (Abstract)

FAHMY, M.H. and BERNARD, C. (1971). Causes of mortality in Yorkshire pigs from birth to 20 weeks of age. Can. J. Anim. Sci. 51, 351-359

FOWLER, V.R. (1980). The nutrition of weaner pigs. Pig News and Information 1, 11-15

FRASER, A.F. (1966). Studies of piglet husbandry in Jamaica. 2. Principal causes of loss between birth and weaning. Br. vet. J. 112, 325-332

FRASER, A.F. (1970). Field observations in Jamaica on thermal agalactia in the sow. Trop. Anim. Hlth. Prod. 2, 175-181

FREDEEN, H.T. (1957). Crossbreeding and swine production. Anim. Breed. Abstr. 25, 339-347

FRIEND, D.W. (1974). Effect on the performance of pigs from birth to market weight of adding fat to the lactation diet of their dams. J. Anim. Sci. 39, 1073-1081

FRIEND, D.W., GORRILL, A.D.L. and MACINTYRE, T.M. (1970). Performance and proteolytic enzyme activity of the suckling piglet creep-fed at 1 or 3 weeks of age. Can. J. Anim. Sci. 50, 349-354

FRIEND, D.W., CUNNINGHAM, H.M. and NICHOLSON, J.W.G. (1962). The duration of farrowing in relation to the reproductive performance of Yorkshire sows. Can. J. comp. Med. 26, 127-130

GLASTONBURY, J.R.W. (1976). A survey of preweaning mortality in the pig. Aust. Vet. J. 52, 272-276

GOONERATNE, A., HARTMANN, P.E., McCAULEY, I. and MARTIN, C.E. (1979). Control of parturition in the sow using progesterone and prostaglandin. Aust. J. Biol. Sci. 32, 587-595

GRACEY, J.F. (1955). Survey of pig losses. Vet. Rec. 67, 984-990

HAKKARAINEN, J. (1975). Developmental changes of protein, RNA, DNA, lipid and glycogen in the liver, skeletal muscle and brain of the piglet. Acta vet. scand. (Suppl. 59) 59, 1-198

HAMMOND, D. and CARLYLE, W.W. (1976). Controlled farrowing on commercial pig breeding units using cloprostenol, a synthetic analogue of prostaglandin $\mathrm{F}_{2 \alpha}$. 8th Int. Congr. Anim. Reprod. A. I., Krakow, 102 (Abstract)

HAYES, R.L. and VAN DEMARK, N.L. (1952). Effects of hormones on uterine motility and sperm transport in the perfused genital tract of the cow. $J$. Dairy Sci. 35, 499-500 (Abstract)

HENDRIX, W.F., KELLEY, K.W., GASKINS, C.T. and HINRICHS, D.J. (1978). Porcine neonatal survival and serum gamma globulins. J. Anim. Sci. 47, 1281-1286

HILLYER, G.M. and PHILLIPS, P. (1980). The effect of increasing feed level to sows and gilts in late pregnancy on subsequent litter size, litter weight and maternal body weight change. Anim. Prod. 30, 469 (Abstract)

HUTCHINSON, H.D., TERRILL, S.W., MORRILL, C.C., NORTON, H.W., MEADE, R.J., JENSEN, A.H. and BECKER, D.E. (1954). Causes of baby pig mortality. J. Anim. Sci. 13, 1023 (Abstract)

ILANCIC, D., NIKOLIC, P. and PAVLOVIĆ, D. (1968). Analysis of farrowing and 
mortality during suckling in a herd of white meat pigs. Vet. Glasn. 22, 601-607

KENWORTHY, R. (1967). Intestinal malabsorption and diarrhoea in the newly weaned pig. M.V.Sc. Thesis. University of Liverpool.

KOTARBINSKA, M. Level of feeding in late pregnancy of the sow. Unpublished data

LECCE, J.G. and MATRONE, G. (1960). Porcine neonatal nutrition:the effect of diet on blood serum proteins and performance of the baby pig. $J$. Nutr. 70, 13-20

LEE, CHANG WOO (1977). Effects of oxytocin and parasympathomimetic drugs on porcine stillbirths. Korean J. vet. Res. 17, 9-12

LEMAN, A.D., KNUDSON, C., RODEFFER, H.E. and MUELLER, A.G. (1972). Reproductive performance of swine on 76 Illinois farms. J. Am. vet. med. Ass. 161, 1248-1250

LODGE, G.A. (1972). Quantitative aspects of nutrition in pregnancy and lactation. In Pig Production (D.J.A. Cole, Ed.), pp. 399-416. London, Butterworths

LODGE, G.A., ELSLEY, F.W.H. and MACPHERSON, R.M. (1966a). The effects of level of feeding of sows during pregnancy. 1. Reproductive performance. Anim. Prod. 8, 29-38

LODGE, G.A., ELSLEY, F.W.H. and MACPHERSON, R.M. (1966b). The effects of level of feeding of sows during pregnancy. II. Changes in body weight. Anim. Prod. 8, 499-506

McINNES, A.A. (1977). Unpublished data - personal communication

MACPHERSON, R.M. and JONES, A.S. (1976). The effect of administration of glucose on survival of the neonatal pig. Anim. Prod. 22, 153 (Abstract)

MARTIN, C.E. and THREFALL, W.R. (1970). Clinical evaluation of hormone therapy in the agalactia syndrome of sows. Vet. Rec. 87, 768-771

MEAT and LIVESTOCK COMMISSION (1980). MLC Commercial Pig Yearbook 1980

MILLER, J.A. and MILLER, F.S. (1965). Studies on prevention of brain damage in asphyxia. Dev. Med. Child Neurol. 7, 607-619

MOORE, R.W., REDMOND, H.E. and LIVINGSTON, C.W. (1965). Iron deficiency anaemia as a cause of stillbirths in swine. J. Am. vet. med. Ass. 147, $746-748$

MOUNT, L.E. (1972). Environmental physiology in relation to pig production. In Pig Production (D.J.A. Cole, Ed.), pp. 71-90. London, Butterworths

MUHRER, M.E., SHIPPEN, O.F, and LASLEY, J.F. (1955). The use of oxytocin for initiating parturition and reducing farrowing time in sows. J. Anim. Sci. 14, 1250 (Abstract)

MURDOCH, Y.P. (1980). Effects of isolating newborn piglets from the sow for varying periods on the duration of farrowing. BSc (Hons) Dissertation. University of Aberdeen

NEWLAND, H.W., MacMILLEN, W.N. and REINEKE, E.P. (1952). Temperature adaptation in the baby pig. J. Anim. Sci. 11, 118-133

NIELSEN, N.C., CHRISTENSEN, K., BILlE, N. AND LARSEN, J.L. (1974). Preweaning mortality in pigs. 1. Herd investigations. Nord. VetMed. 26, $137-150$

O'GRADY, J.F. (1967). Effect of level and pattern of feeding during 
pregnancy on weight change and reproductive performance of sows. Ir. J. agric. Res. 6, 57-71

OKAI, D.B., AHERNE, F.X. and HARDIN, R.T. (1976). Effects of creep and starter composition on feed intake and performance of young pigs. Can. J. anim. Sci. 56, 573-586

OKAI, D.B., AHERNE, F.X. and HARDIN, R.T. (1977). Effects of sow nutrition in late gestation on the body composition and survival of the neonatal pig. Can. J. anim. Sci. 57, 439-448

OKAI, D.B., WYLLIE, D., AHERNE, F.X. and EWAN, R.C. (1978). Glycogen reserves in the foetal and newborn pig. J. Anim. Sci. 46, 391-401

POMEROY, R.W. (1960). Infertility and neonatal mortality in the sow. III. Neonatal mortality and foetal development. J. agric. Sci., Camb. 54, $31-56$

RANDALL, G.C.B. (1972a). Observations on parturition in the sow. 1. Factors associated with the delivery of the piglets and their subsequent behaviour. Vet. Rec. 90, 178-182

RANDALL, G.C.B. (1972b). Observations on parturition in the sow. 2. Factors influencing stillbirth and perinatal mortality. Vet. Rec. 90, 183-186

RANDALL, G.C.B. and PENNY, R.H.C. (1967). Stilibirth in pigs: the possible role of anoxia. Vet. Rec. 81, 359-361

RANDALL, G.C.B. and PENNY, R.H.C. (1970). Stillbirth in the pig: An analysis of the breeding records of five herds. Br. vet. J. 126, 593-603

REEDY, L.P., HEIDENREICH, C.J., FOLEY, C.W. and CURTIS, S.E. (1966). Orally-administered glucose effects on swine. J. Anim. Sci. 25, 1267 (Abstract)

RINGARP, N. (1960). A post-parturient syndrome with agalactia in sows. Acta Agric. Scand., Suppl., 7,

ROBERTSON, J.B., LAIRD, R., HALL, J.K.S., FORSYTH, R.J., THOMPSON, J.M. and WALKER-LOVE, J. (1966). A comparison of two indoor farrowing systems for sows. Anim. Prod. 8, 171-178

SCOTT, G.T. (1981). Development of a system of artificial rearing for piglets surplus to the sow's rearing capacity and evaluation of its repercussions. $\mathrm{PhD}$ Thesis. University of Aberdeen

SCOTT, G.T. and PRINGLE, R.T. (1976). Experiments on complementary artificial rearing of piglets. 3. Feeding system and cages. Fm. Building Prog. 45, 23-28

SEERLEY, R.W., PACE, T.A., FOLEY, C.W. and SCARTH, R.D. (1974). Effect of energy intake prior to parturition on milk lipids and survival rate, thermostability and carcass composition of piglets. J. Anim. Sci. 38, 64-70

SHARPE, H.B.A. (1966). Preweaning mortality in a herd of Large White pigs. Br. vet. J. 122, 99-111

SMITH, C. and KING, J.W.B. (1964). Crossbreeding and litter production in British pigs. Anim. Prod. 6, 265-271

SPRECHER, D.J. LEMAN, A.D. and CARLISLE, S. (1975). Effects of parasympathomimetics on porcine stillbirth. Am. J. vet. Res. 36, 1331-1333

SPRECHER, D.J., LEMAN, A.D., DZUIK, P.D., CROPPER, M. and DEDECKER, M. (1974). Causes and control of swine stillbirth. J. Am. vet. med. Ass. 165, 698-701 
STANTON, H.C. and CARROLL, J.K. (1974). Potential mechanisms responsible for prenatal and perinatal mortality or low viability of swine. J. Anim. Sci. 38, 1037-1044

TITTERINGTON, R.W. and FRASER, D. (1976). The lying behaviour of sows and piglets during early lactation in relation to the position of the creep heater. Appl. Anim. Ethol. 2, 47-53

TURNBULL, A.C. and ANDERSON, A.B.M. (1968). Induction of labour. Part II. Intravenous oxytocin infusion. J. Obstet. Gynaec. Br. Commonw. 75, 24-31

VARLEY, M.A. and BROOKING, P. (1981). The control of parturition in the sow using an oral progestagen. Anim. Prod. 32, 369 (Abstract)

WALKER, N. (1977). The effects of induction of parturition in sows using an analogue of prostaglandin $F_{2 \alpha}$. J. agric. Sci., Camb. 89, 267-271

WILKINSON, V. and ENGLISH, P.R. (1981). Unpublished data

WRATHALl, A.E. (1971). Prenatal survival in pigs. Part 1. Ovulation rate and its influence on prenatal survival and litter size in pigs. Commonw." Bur. Anim. Hlth Rev. Ser. 9, Slough, UK, Commonwealth Agricultural Bureaux

YOUNG, G.A. and UNDERDAHL, N.R. (1953). Isolation units for growing baby pigs without colostrum. Am. J. vet. Res. 14, 571-574 